O特集 上皮細胞膜の特性と機能

\title{
胃壁細胞における胃酸分泌の分子基盤
}

\author{
浅野真司 \\ 立命館大学 薬学部 \\ 于 525-8577 滋賀県草津市野路東 1-1-1
}

\section{Molecular Basis of Gastric Acid Secretion in Parietal Cells}

\author{
Shinji Asano \\ College of Pharmaceutical Sciences, Ritsumeikan University \\ 1-1-1, Noji-Higashi, Kusatsu-city, Shiga 525-8577, Japan
}

Gastric acid secretion in parietal cells is performed by proton pump, $\mathrm{H}^{+}, \mathrm{K}^{+}-$ATPase, in combination with several related ion transporters located on the apical and basolateral membranes. In this review I will introduce several recent topics about molecular basis of gastric acid secretion in parietal cells. First, I wish to introduce 3D structures of $\mathrm{H}^{+}, \mathrm{K}^{+}$-ATPase resolved recently. The structures demonstrated the interaction between the $\alpha$ - and $\beta$ - subunits fixes and favors the E2P conformation (the "rachet effect"). The binding site of a $\mathrm{K}^{+}$-competitive inhibitor $\mathrm{SCH}$ 28080 on the $\alpha$ - subunit of $\mathrm{H}^{+}, \mathrm{K}^{+}$- ATPase was also identified in the 3D structure. Secondly, I wish to introduce ion transporters on the apical membrane necessary for gastric acid secretion. Among others KCNQ1/KCNE2 was identified as a $\mathrm{K}^{+}$channel involved in $\mathrm{K}^{+}$recycling and replenishment of $\mathrm{K}^{+}$in the lumen. Thirdly, I wish to introduce actin-binding proteins, ezrin and Huntingtin interacting protein 1 related (Hip1r), which are necessary for gastric acid secretion. Ezrin is involved in membrane fusion between tubulovesicles and apical membrane whereas Hip1r is involved in endocytosis and regeneration of tubulovesicles from apical membrane. Finally, the roles of parietal cells in differentiation of gastric epithelial cells as well as gastric acid secretion will be introduced.

Key words : gastric acid secretion $/$ proton pump $/$ membrane fusion $/$ actin-binding protein

\section{1. はじめに}

胃酸の分泌は，胃底腺に存在する胃壁細胞によっ て行われる. Fig. 1に示すように胃壁細胞内では炭酸 脱水酵素の働きによって炭酸ガスと水から炭酸が形 成される，炭酸はプロトンと重炭酸イオン $\left(\mathrm{HCO}_{3}{ }^{-}\right)$ とに開裂し, $\mathrm{HCO}_{3}{ }^{-}$は基底側膜に存在する $\mathrm{Cl}^{-}$/ $\mathrm{HCO}_{3}{ }^{-}$輸送体（AE2）によって血液中に輸送される. 一方, プロトンは頂端膜に存在する胃酸分泌プロト

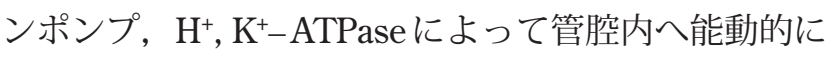

Tel: +81-77-561-5908

Fax: +81-77-561-5908

E-mail: ashinji@is.ritsumei.ac.jp
輸送される．これが酸分泌にあたる．最近になって， 胃酸分泌プロトンポンプの立体構造が報告され, 同 じファミリーの ATPaseである SERCA $\mathrm{Ca}^{2+}$ ATPase や $\mathrm{Na}^{+}, \mathrm{K}^{+}-$ATPase では見られない特徵的な 構造が明らかになった，本稿では，まずこの点につ いて紹介する.

胃酸分泌プロトンポンプによるプロトン輸送活性 は, 胃壁細胞に存在するさまざまなイオン輸送体の 活性と連関しており, それらによって巧みな機能調 節を受ける。その代表的なものが頂端膜に発現する $\mathrm{K}^{+}$のリサイクリングに関わる輸送体（チャネル?） であり, $\mathrm{Cl}^{-}$の分泌を行う輸送体（チャネル?）であ る.これらの輸送体については胃酸分泌プロトンポ ンプと比較して特定が遅れていたが, 近年, 遺伝子 


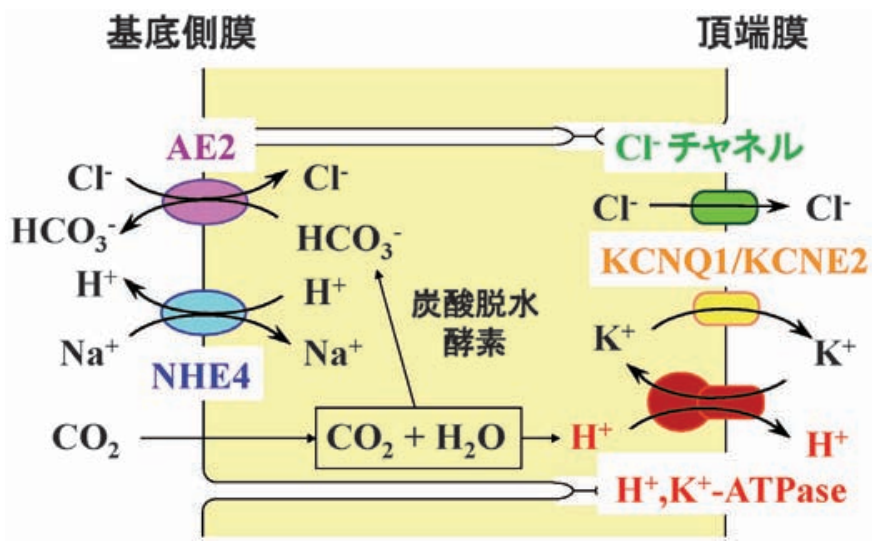

Fig. 1 Gastric acid secretion by parietal cells is performed by the combined operation of gastric proton pump, several ion transporters and carbonic anhydrase.

Carbonic anhydrase catalyzes a reaction producing proton and $\mathrm{HCO}_{3}{ }^{-}$from water and $\mathrm{CO}_{2}$. Proton is actively transported into gastric lumen by gastric proton pump, $\mathrm{H}^{+}, \mathrm{K}^{+}-\mathrm{ATPase}$ whereas $\mathrm{HCO}_{3}^{-}$is transported into blood by a $\mathrm{Cl}^{-} / \mathrm{HCO}_{3}{ }^{-}$exchanger, AE2. KCNQ1/KCNE2 located on the apical membrane is involved in replenishment of $\mathrm{K}^{+}$in the lumen. $\mathrm{Cl}^{-}$channel(s) or transporter(s) on the apical membrane are also involved in gastric acid secretion.

クローニングや, 遺伝子改変動物のフェノタイプ解 析などによって同定が進みつつある。この点につい ても最近の研究の動向を紹介する.

胃壁細胞は分泌刺激を受けると, 細胞内に存在す るプロトンポンプを含んだ細管小胞が管腔側膜と融 合して微絨毛を発達させて，プロトンポンプによる 酸分泌を活性化させる。一方, 分泌刺激が除かれる と，管腔側膜から細管小胞が再構成されるものと見 られる.したがって, 胃酸分泌にはアクチン細胞骨 格系のダイナミックな再構成を伴い, 膜融合やエン ドサイトーシスに関わるタンパク質の関与が重要で ある。本稿では, Huntingtin interacting protein 1 related (Hip1r)とエズリンという2 種類のアクチン結 合タンパク質の胃酸分泌に対する関与についても紹 介する.

また, 胃壁細胞は胃酸分泌機能のほかに, 胃粘膜 を構成する細胞に栄養因子を分泌して分化を促し, 胃粘膜の組織構築に働くことが知られている。本稿 の最後では，この点についても紹介したい.

\section{2. 胃酸分泌プロトンポンプ}

\section{1 胃酸分泌プロトンポンプの基本的な構造}

胃酸分泌プロトンポンプは前述のように $\mathrm{H}^{+}, \mathrm{K}^{+}-$
ATPase とも呼ばれ，ATPの加水分解のエネルギーを 利用して, 細胞外 (管腔内) の $\mathrm{K}^{+}$を細胞内に輸送す るのと交換に胃壁細胞内のプロトンを管腔内へと分 泌して 100 万倍以上のプロトンの濃度勾配を形成す る.プロトンポンプによるATPの加水分解時には, ATP結合ポケットに存在するアスパラギン酸残基が リン酸化されて安定なアシルリン酸中間体（EPと呼 ばれる）が形成されることから，同様な EP中間体を 形成する膜輸送ATPase とともにP-type ATPase と総 称されている.

プロトンポンプは触媒サブユニットである $\alpha$ 鎖 （ATP4A）と，非触媒サブユニットである $\beta$ 鎖 (ATP4B) から構成される。 $\alpha$ 鎖は分子量がおよそ $110 \mathrm{kDa}$ の膜 10 回貫通型のタンパク質で, ATPの結 合部位, リン酸化部位, イオンの結合部位のほか, 消化性潰瘍や逆流性食道炎の治療剤として用いられ ているプロトンポンプ阻害剤の結合部位を含む。 $\alpha$ 鎖の一次構造は $\mathrm{Na}^{+}, \mathrm{K}^{+}-$ATPase $の ~ \alpha$ 鎖や，骨格筋な どに存在するSERCAなどと高い相同性を持つ.一方, $\beta$ 鎖はタンパク質部分の分子量が $33 \mathrm{kDa}$ で, $\mathrm{N}$ 末端 の約 32 アミノ酸残基を細胞質内にもつ膜 1 回貫通型

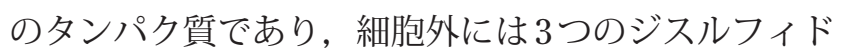
結合と, $6 \sim 7$ 本の糖鎖を含む. $\beta$ 鎖は $\mathrm{H}^{+}, \mathrm{K}^{+}-$ ATPase と $\mathrm{Na}^{+}, \mathrm{K}^{+}-$ATPaseのファミリーのみに特徵 的に見られるサブユニットで， $\alpha$ 鎖の細胞表面への 輸送や, 膜中での安定化に㗢くことが知られている. プロトンポンプは膜中で複数の $\alpha$ 鎖, $\beta$ 鎖からなる ヘテロオリゴマー構造をとって機能を発揮する ${ }^{1,2)}$.

\section{2 胃酸分泌プロトンポンプの反応機構}

胃酸分泌プロトンポンプはATPを加水分解してプ ロトンと $\mathrm{K}^{+}$とを能動輸送する過程でいくつかの異な るコンホメーションをとり, Fig. 2 に示すような反応 スキームとして表わされる。その概要は以下の通り である。（1）酵素（プロトンポンプ）（図中で Eとし て表現する）が細胞内の ATP，プロトンと反応して E1-ATP- $\mathrm{H}^{+}$を形成する。（2）ATPのリン酸基を受容 してリン酸化中間体 $\mathrm{E} 1 \mathrm{P}-\mathrm{H}^{+}$に変化する．（3）プロ トンを細胞質側から管腔側に輸送して, E1P- $\mathrm{H}^{+}$から E2P- $\mathrm{H}^{+}$に変化する。（4）E2P- $\mathrm{H}^{+}$が管腔側にプロト ンを遊離して, E2Pへとコンホメーション変化する. （5） E2Pが管腔内の $\mathrm{K}^{+}$と反応して, 脱リン酸化を受

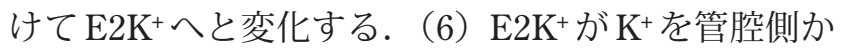
ら細胞質に輸送して，もとの $\mathrm{E} 1$ とコンホメーショ ン変化する（図中では, $\mathrm{E} 2 \mathrm{~K}^{+}$が ATP と反応して E1-ATPが形成される)。ここでいう $\mathrm{E}_{1}$ コンホメーシ ヨンとは，イオンの結合部位を細胞質側に向けて開 き, プロトンに対して高い親和性を示す構造を, $\mathrm{E}_{2}$ 


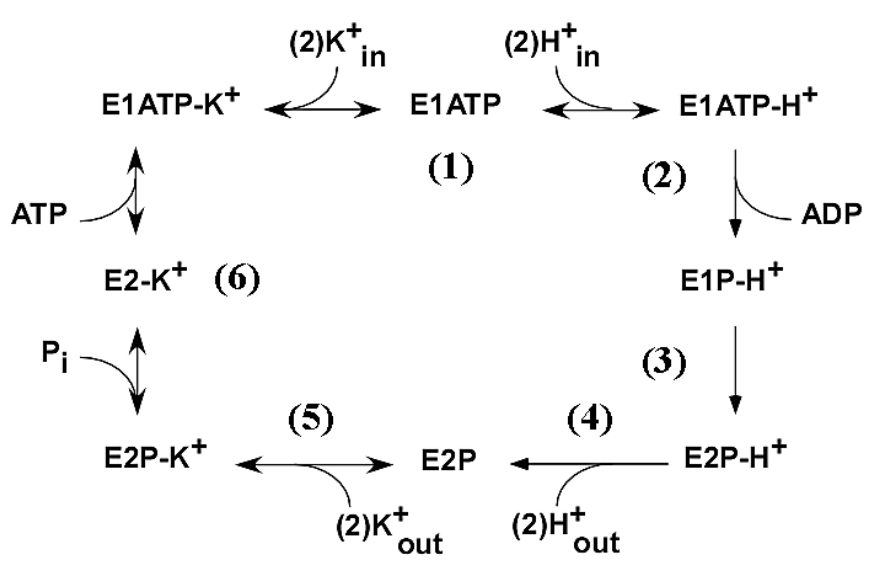

Fig. 2 Reaction cycle of gastric proton pump, $\mathrm{H}^{+}, \mathrm{K}^{+}-$ ATPase.

In this reaction cycle, EPs represent phosphorylated intermediates of $\mathrm{H}^{+}, \mathrm{K}^{+}$-ATPase. E1 and E2 represent enzymes with the ion-binding site facing to the cytoplasmic or luminal side, respectively. It is noteworthy that the reaction(s) from E1P- $\mathrm{H}^{+}$to E2P of the gastric $\mathrm{H}^{+}, \mathrm{K}^{+}-\mathrm{ATPase}$ are almost irreversible.

コンホメーションとは，イオンの結合部位を管腔側 に向けて開き， $\mathrm{K}^{+} に$ 対して高い親和性を示す構造を いう.これらの各過程の反応は基本的に可逆的な反 応であるが，プロトンポンプは $\mathrm{E} 1 \mathrm{P}-\mathrm{H}^{+}$と $\mathrm{E}_{2} \mathrm{P}$ との平 衡が著しく $\mathrm{E}_{2} \mathrm{P}$ に偏るという他に見られない特性を もち, 逆反応による $\mathrm{E} 1 \mathrm{P}-\mathrm{H}^{+}$の形成はほとんど起こ らない.このことが管腔側から細胞質側へのプロト ンの逆流を阻止するものと思われたが，こうしたこ とを可能にしている反応機構については知られてい なかった。

\section{3 胃酸分泌プロトンポンプの立体構造}

胃酸分泌プロトンポンプの $\alpha$ 鎖は, 前述のように SERCAや $\mathrm{Na}^{+}, \mathrm{K}^{+}-$ATPase $の ~ \alpha$ 鎖と高い相同性を持 ち, ATP結合部位やアシルリン酸化部位を形成する アミノ酸はよく保存され, 膜貫通ドメインに存在す るイオン結合部位を構成するアミノ酸も保存された ものが多い，そうしたことから，プロトンポンプの 構造と機能との関連は, プロトンポンプでの部位特 異的な変異導入法による実験結果を, 東京大学の豊 島教授のグループなどが発表した SERCAの結晶構 造3〜7)（あるいは，最近になって発表された $\mathrm{Na}^{+}$, $\mathrm{K}^{+}$-ATPaseの結晶構造 ${ }^{8,9}$ ) ) を基にしたホモロジーモ デリングによる仮想の構造上で検証する形で研究さ れてきた。その結果，プロトンポンプの $\alpha$ 鎖の細胞 質構造が, N(Nucleotide-binding) ドメイン, P (Phosphorylation) ドメイン, A(Actuator) ドメイン という三つのドメインからなり, 反応過程でこれら
のドメインの位置関係が大きく変化すること． 4,5 , 6,8 番目の膜貫通領域に存在するおもに酸性のアミ ノ酸（Asp, Glu）の側鎖や，極性アミノ酸側鎖，4番 目の膜貫通領域に存在する酸性アミノ酸残基（Glu） 近傍のアミノ酸の主鎖が $\mathrm{K}^{+}$を結合することなどが明 らかになった1110,11). しかしながら，ホモロジーモデ リングでは, 胃酸分泌プロトンポンプについての固 有な反応特性, 例えば 100 万倍近いプロトンの濃度勾 配を作りながらプロトンの逆流を阻止できる機構や， プロトンがどのような形で輸送されるのか（ $\mathrm{H}^{+}$とし てか，あるいは $\mathrm{H}_{3} \mathrm{O}^{+}$としてか）などについては不明 のままであった.

最近になって京都大学の阿部博士らはブタの胃粘 膜から精製したプロトンポンプの二次元結晶の電子 顕微鏡解析によって, $6.5 \AA$ の分解能で $\mathrm{E}_{2} \mathrm{P}$ コンホメ ーションを, $7 \AA$ の分解能でプロトンポンプの阻害剂 である SCH 28080 結合型の $\mathrm{E}_{2} \mathrm{P} *$ コンホメーション

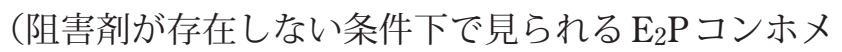
ーションとは異なるため, $\mathrm{E}_{2} \mathrm{P}^{*}$ コンホメーションと 命名した）の立体構造を明らかにした ${ }^{12,13)}$. プロト ンポンプの立体構造は, ホモロジーモデリングによ

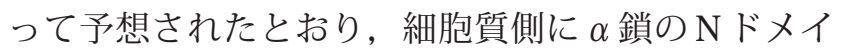

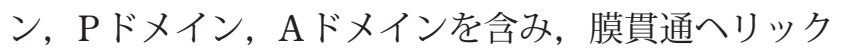
スとして $\alpha$ 鎖の 10 本， $\beta$ 鎖の1本のヘリックスが確

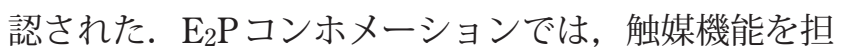
う $\alpha$ 鎖の立体構造に加えて, 新たに非触媒サブユニ ットである $\beta$ 鎖が $\alpha$ 鎖と相互作用して酵素活性を制 御することが示された. 即ち細胞質中に存在する $\beta$ 鎖の $\mathrm{N}$ 末端領域が $\alpha$ 鎖の $\mathrm{P}$ ドメインと反応して, 酵

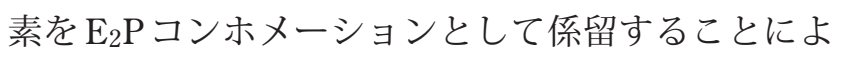
って, $\mathrm{E}_{2} \mathrm{P}$ コンメーションから $\mathrm{E}_{1} \mathrm{P} コ$ コメーショ ンへの逆反応を妨げるものと見られた. 実際に $\beta$ 鎖 の $\mathrm{N}$ 末端から 8 残基以上欠損させた変異体を発現さ

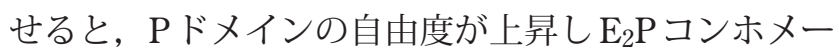

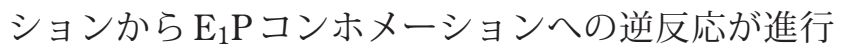
することが示された。こうした実験事実をもとに阿 部博士らは, この現象をプロトンポンプの「ラチェ ット機構」と呼び, プロトンポンプが 100 万倍ものプ ロトン濃度勾配を効率よく形成し, 逆反応によるプ ロトンの逆流を起こさない為に備わった機構である としている ${ }^{12)}$.

また, SCH 28080 結合型の $\mathrm{E}_{2} \mathrm{P}^{*}$ コンホメーション では,これまでに部位特異的な変異導入実験等で SCH 28080 との反応に関わると報告されていた $\alpha$ 鎖 の 4，5，6番目の膜貫通領域のアミノ酸残基（F332, A335, Y799, L809, C813）に囲まれた構造が SCH 28080 結合部位として確認された（C813 はオメプラ ゾールなどプロトンポンプ阻害剤の結合部位として 
も知られている). SCH 28080 結合型の $\mathrm{E}_{2} \mathrm{P}^{*}$ コンホ メーションでは, SCH 28080 が結合した結果, 1～4 番目の膜貫通領域がシフトし, 細胞質側の立体構造 までも変化させる，その結果， $\mathrm{E}_{2} \mathrm{P} *$ コンホメーショ

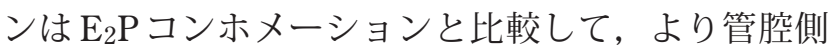
に開いたコンホメーションをとることが確認され た ${ }^{13)}$.

また, 富山大学の森井教授 (現 鈴鹿医療科学大学) らはブタの胃粘膜由来の細管小胞を用いて，130 mM $\mathrm{K}^{+}$と $\mathrm{K}^{+}$イオノフォアであるバリノマイシンの存在下 で, 小胞内への安定放射性同位体標識した水 $\left(\left[{ }^{18} \mathrm{O}\right] \mathrm{H}_{2} \mathrm{O}\right)$ の輸送の測定を行った ${ }^{14)}$. $\left.{ }^{[18} \mathrm{O}\right] \mathrm{H}_{2} \mathrm{O}$ の 小胞内への輸送はMgATP添加によって活性化され, またプロトンポンプ阻害剤SCH 28080 によって特異 的に阻害された。ささに, 加水分解されるATP と輸 送される水分子の化学量論比は $1: 1.8$ となり, プロ トン輸送に見られるATP とプロトンとの化学量論比 1：2 とよく一致した. 以上の結果から, プロトンポ ンプによって輸送されるプロトンの実体はオキソニ ウムイオン $\left(\mathrm{H}_{3} \mathrm{O}^{+}\right)$であることが考えられた。この 実験結果は, プロトンポンプがATPの加水分解と共 役してプロトンとともに水を輸送することを意味す る. 生理的には胃酸分泌時に塩酸とともに多量の水 が管腔内に分泌されるが, 胃壁細胞の管腔膜にはア クアポリン (AQP) が見出されないこと（基底側膜 にはAQP4が発現することが確認されている), また, 傍細胞輸送（タイトジャンクションを通した細胞間 輸送）による大量の水輸送は考えにくいことから， これまでは水輸送を行う実体は明らかではなかった。 プロトンポンプ自体が管腔内に水輸送を行うとすれ ば，この問題は説明できるのかも知れない.

\section{3. 胃酸分泌プロトンポンプと膜輸送タンパ ク質との機能連関}

\section{$3.1 K^{+}$のリサイクリングを行う輸送体}

胃酸分泌プロトンポンプはプロトンと $\mathrm{K}^{+}$とを対抗 輸送することから，プロトンポンプによるプロトン 輸送, 即ち酸分泌が持続的に行われる為には, 管腔 内への $\mathrm{K}^{+}$の供給が必要であり, $\mathrm{K}^{+}$の供給の度合によ って胃酸分泌活性は制御されることになる (Fig. 3). 管腔内への $\mathrm{K}^{+}$の供給（細胞内から管腔内への外向き の $\mathrm{K}^{+}$の動き : プロトンポンプが輸送した $\mathrm{K}^{+}$のリサイ クリング）を補償する $\mathrm{K}^{+}$チャネルとして KCNQ1 と， 内向き整流性の $\mathrm{K}^{+}$チャネル Kir4.1 (KCNJ10)などが考 えられてきた。最近になってハノーバー大学の Song らは KCNQ1，Kir4.1それぞれのノックアウトマウス を用いて，両者の生理的な機能を比較する興味深い

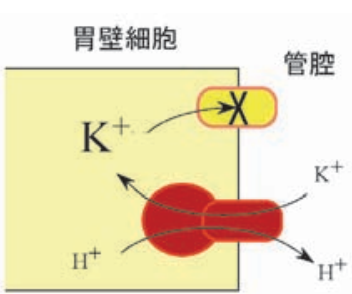

胃酸分泌休止状態

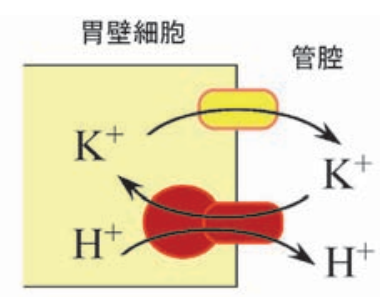

胃酸分泌活性化状態
Fig. 3 Functional interaction between gastric proton pump and $\mathrm{K}^{+}$channel (or transporter) on apical membrane.

Gastric proton pump actively exchanges intracellular proton with $\mathrm{K}^{+}$in gastric lumen. In this process, the activity of proton pump is regulated by the $\mathrm{K}^{+}$ channel. When the $\mathrm{K}^{+}$channel is absent on the apical membrane, or inhibited by its inhibitor, chromanol 293 , luminal $\mathrm{K}^{+}$is not replenished resulting in decrease in the proton pump activity (resting condition shown on the left side). When the $\mathrm{K}^{+}$channel is present and active on the apical membrane, luminal $\mathrm{K}^{+}$is replenished resulting in increase in the proton pump activity (stimulated condition shown on the right side).

研究成果を報告した ${ }^{15,16}$. KCNQ1は元久, 心室性の 不整脈を引き起こす家族性の QT延長症候群の原因遺 伝子として見出された膜 6 回貫通型の電位依存性の $\mathrm{K}^{+}$チャネルである. KCNQ1 は, 会合する膜 1 回貫通 型の補助サブユニット KCNEの種類によってチャネ ル特性を変えるが, 胃壁細胞では KCNE2 と会合した 形で管腔側膜に存在しており, KCNQ1/ KCNE2が $\mathrm{K}^{+}$を細胞外へとリサイクルすることによって, プロ トンポンプの機能を活性化するものと考えられた。 実際に, KCNQ1に対する特異的な阻害剂である chromanol 293 で処理すると胃酸の分泌は完全に阻害 される ${ }^{17)}$. KCNQ1に対するノックアウトマウスでは, 胃壁細胞数やプロトンポンプの発現には変化が見ら れないが, 胃酸分泌刺激を加えない基礎的な酸分泌 も，アデニル酸シクラーゼの活性化剤であるフォル スコリン刺激による酸分泌充進も傷害された。

一方, 管腔側に saline（154 mM Na+） に替えて 154 $\mathrm{mM} \mathrm{K} \mathrm{K}^{+}$を補充すると酸分泌の回復が観察され た ${ }^{15)}$. 以上の結果から, KCNQ1はプロトンポンプの 活性に必要な $\mathrm{K}^{+}$を管腔側に補充, リサイクルする $\mathrm{K}^{+}$ チャネルであると考えられた，このことは，KCNQ1 の補助サブユニットである KCNE2 に対するノックア ウトマウスでも胃酸分泌傷害が扔こることによって 裏付けられる18).

胃壁細胞において $\mathrm{K}^{+}$のリサイクリングを行う $\mathrm{K}^{+}$チ 
ヤネルの候補としては, KCNQ1 とは別に Kir4.1があ る. Kir4.1は休止状態の細管小胞，胃酸分泌刺激状態 の管腔側膜において胃酸分泌プロトンポンプと共局 在すること, 胃酸分泌プロトンポンプと免疫共沈殿 されることから，プロトンポンプの機能を調節する チャネルであることが予想された ${ }^{19)}$. Kir4.1に対す るノックアウトマウスは胎生致死になることなく誕 生するが, ホモマウスは神経系に異常を生じ, 生後 2 週間以内に完全に死滅することから，成熟したマウ スを用いてフェノタイプを解析することはできなか った. Song らは 7〜8日齢のマウスの胃粘膜を用い て実験を行った．Kir4.1のノックアウトマウスの胃酸 分泌に打けるフェノタイプは予想に反して KCNQ1の ノックアウトマウスのものと大きく異なり, 胃酸分 泌の障害ではなく，むしろ充進が観察された．基礎 的な酸分泌は野生型と同等であったが，フォルスコ リン刺激下では野生型と比較して酸分泌速度の上昇, 分泌量の増加が観察された。一方，管腔側に salineに 替えて $154 \mathrm{mM} \mathrm{K}^{+}$を用いても酸分泌の活性化は観察 されなかった．胃粘膜における胃壁細胞の数には変 化が見られないものの, mRNA, タンパク質レベル でプロトンポンプの発現上昇が観察された. 更に興 味深いことに胃壁細胞を電子顕微鏡で観察すると, 酸分泌刺激を加えない条件下においてすでに細管小 胞が著明に減少し, 管腔膜に微絨毛の発達が認めら れ, 酸分泌刺激状態に近い形態が観察された。こう した事実から Kir4.1は, 胃壁細胞が刺激状態から休 止状態へと戻る際に，エンドサイトーシスによって 管腔膜から細管小胞が再形成される段階に働くこと が考えられた。 また，Kir4.1は， $\mathrm{K}^{+}$のリサイクリン グに働きプロトンポンプを活性化させる方向に働く のではなく，KCNQ1/KCNE2 チャネルによる管腔へ の $\mathrm{K}^{+}$のリサイクリングと, プロトンポンプによる管 腔からの $\mathrm{K}^{+}$の吸収との間で調節的に作用を行い, 細 胞からの $\mathrm{K}^{+}$の過剩な喪失を抑えてプロトンポンプに 対して負の抑制をかけるチャネルであることが明ら かになった ${ }^{16)}$.

富山大学の藤井博士らは $\mathrm{K}^{+}$チャネルとは別に $\mathrm{K}^{+}-\mathrm{Cl}^{-}$共輸送体 $\mathrm{KCC}$ のメンバーである $\mathrm{KCC} 4$ が胃酸 分泌に関わることを報告した ${ }^{20)}$. KCC4は胃壁細胞に 発現するが，細管小胞には存在せず，管腔側膜で胃 酸分泌プロトンポンプと会合する形で発現する。管 腔側膜由来の小胞（stimulation-associated vesicles） を用いた実験では，プロトンポンプ阻害剤 SCH 28080 によって KCC4 による $\mathrm{Cl}^{-}$輸送が阻害される. 同様に KCC4 阻害剤 DIOAによってプロトンポンプ活 性が阻害される。また, HEK293細胞では, プロトン ポンプに KCC4 を共発現させると, 細胞のプロトン
輸送活性が充進する．こうした事実から，KCC4は管 腔側膜で胃酸分泌プロトンポンプと物理的に会合, 機能連関して管腔内への $\mathrm{K}^{+}$のリサイクリング, $\mathrm{Cl}^{-}$の 分泌に㗢くものと考えられる. KCC4のノックアウト マウスについては聴覚障害や腎臓でのアシドーシス が報告されているが，残念ながら胃酸分泌に関わる フェノタイプについては報告がない21．

\section{$3.2 \mathrm{Cl}^{-}$の分泌を行う輸送体}

プロトンポンプと協調的に働いて塩酸分泌を行う 外向きの $\mathrm{Cl}^{-}$の動きも必要となる。 $\mathrm{Cl}^{-}$の分泌を行う $\mathrm{Cl}^{-}$チャネルの候補として SLC26A9, parchorin (CLIC-6), CFTRなどが胃壁細胞に見出されている. $\mathrm{SLC} 26$ ファミリーのタンパク質は $\mathrm{Cl}^{-} / \mathrm{HCO}_{3}{ }^{-}$交換輸 送体として, または $\mathrm{Cl}^{-}$チャネル（またはアニオンチ ヤネル）として働く. SLC26A9はアフリカツメガエ ルの卵母細胞に発現させると $\mathrm{Cl}^{-}$チャネル活性を, 培 養細胞に発現させると $\mathrm{Cl}^{-} / \mathrm{HCO}_{3}$-交換輸送活性を示 す. SLC26A9 は表面上皮細胞の管腔側膜に発現する ほか, 胃壁細胞の細管小胞にも発現する. SLC26A9 のノックアウトマウスでは, 胃酸分泌はほぼ完全に 消失する. 胃腺中の壁細胞と主細胞の数が減少する ほか, 壁細胞内の細管小胞が消失する.こうした事 実から, SLC26A9は胃壁細胞で細管小胞や分泌膜系 を安定化させること, あるいは $\mathrm{Cl}^{-}$分泌に関わると考 えられる22).

Parchorin は胃壁細胞で酸分泌刺激にともなってリ ン酸化を受ける分子量 $120 \mathrm{kDa}$ のタンパク質として 見出されたもので（胃壁細胞 parietal cells, 脈絡叢 choroid plexusに見られたことから Parchorin と命名 された） ${ }^{23)}$, 細胞内 $\mathrm{Cl}^{-}$チャネル (CLIC) ファミリー タンパク質に相同性を示すことから CLIC-6 と命名さ れた. CLIC-6は LLC-PK1培養細胞などに発現させ ると $\mathrm{Cl}^{-}$透過性が発現することから, $\mathrm{Cl}^{-}$チャネルと みられるが, 休止状態の胃壁細胞では細胞質ゾルに 存在し, 酸分泌刺激にともなって管腔側膜に移動す るという他のチャネルでは見られない興味深い特性 をもつ ${ }^{24,25)}$. 胃酸分泌に関わって $\mathrm{Cl}^{-}$分泌や水輸送に 関わるものと考えられているが，その実態は明らか ではない.

胃酸分泌時の $\mathrm{pH} 0.8$ に対応する塩酸の濃度は 160 $\mathrm{mM}$ となる. $\mathrm{Cl}^{-}$輸送はチャネルを介した受動輸送に よって行えるのであろうか. 藤井博士らは KCC4 に よる $\mathrm{K}^{+}$輸送に駆動される形での $\mathrm{Cl}^{-}$分泌の可能性を 提唱している ${ }^{20)}$. このように胃酸分泌に直接に関わ る $\mathrm{Cl}^{-}$輸送体の実体は， $\mathrm{K}^{+}$のリサイクリングを行う輸 送体としての KCNQ1/KCNE2 ほどには明らかになっ ていない. 


\section{4. 胃酸分泌におけるアクチン結合タンパク 質の働き}

胃壁細胞は, 分泌刺激によって大きな構造変化を 見せる. 即ち，休止状態では分泌管腔の表面積は小 さく, 細胞内に多数の細管小胞が認められる. 胃酸 分泌プロトンポンプの大部分は胃壁細胞内の閉じた 細管小胞上に存在して活動を休止している。これに 対して, 胃壁細胞を酸分泌刺激剂であるヒスタミン で処理すると, 細管小胞が管腔側膜と融合して, 分 泌管腔に微絨毛が発達して表面積を増大させる。こ の過程でプロトンポンプは管腔側膜表面に移動し, $\mathrm{K}^{+}$のリサイクリングに働く $\mathrm{K}^{+}$チャネルなどと機能連 関してプロトンポンプとしての活動を行う 26, 27). 最 近, 胃壁細胞における膜融合の分子機構が明らかに されつつある. 本稿では, アクチン結合タンパク質 である Hip1rタンパク質とエズリンの遺伝子改変マウ スのフェノタイプを紹介し，これらのタンパク質の 胃酸分泌や胃粘膜構築に対する機能について考察す る.

Hip1r は細胞内での小胞輸送にかかわるタンパク質 で，F-アクチン，クラスリンと結合することによっ て両者をクロスリンクする働きをもつ，また，Hip1r タンパク質は胃に高発現し，とりわけ胃壁細胞の管 腔側膜に発現して F-アクチンと共局在する. Hip1r ノックアウトマウスでは管腔側膜が発達する一方で, 細管小胞が見られなくなる．細胞レベルでは胃酸分 泌が亢進された状況と近くなる。他方, 組織レベル ではアポトーシスが京進し胃壁細胞数が減少して胃 内酸性度の低下が観察される。また，ガストリン濃 度が上昇し粘膜表層細胞の過形成が観察される ${ }^{28)}$.

他方，エズリンは $\mathrm{N}$-末端側で細胞膜に存在するタ ンパク質や足場タンパク質と, $\mathrm{C}$-末端側で $\mathrm{F}$-アク チンと結合することによって両者をクロスリンクす る働きをもつ. ウサギから単離した胃底腺をヒスタ ミンで処理すると，プロトンポンプが細管小胞から 管腔側膜へと移行するのと同時に，管腔側膜を含む 画分で, アクチン結合タンパク質であるエズリンの リン酸化が著明に充進する ${ }^{29)}$. エズリンノックダウ ンマウス（エズリン遺伝子のイントロン部分に変異 カセットを導入してエズリンの発現は野生型の $5 \%$ 程 度にまで低下させたマウス）では，ヒスタミン処理 しても, 細管小胞と管腔側膜との融合は認められず, 細胞内に多数の細管小胞が存在し, 胃酸の分泌が傷 害される ${ }^{30)}$. 組織レベルでは胃壁細胞, 主細胞数が 減少して固有胃腺が萎縮するほか副細胞の過剩増殖 が観察される。 また, ガストリン濃度が上昇し, 粘

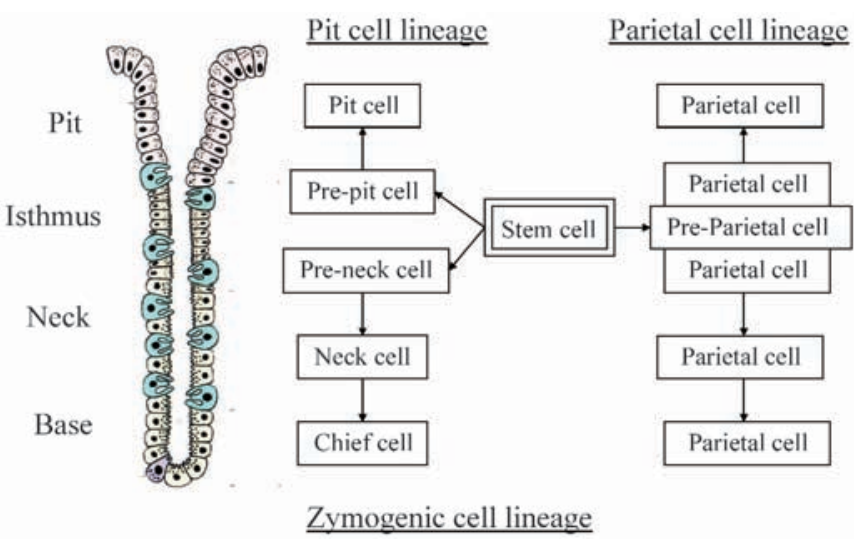

Fig. 4 Shematic representation of the pathways of gastric epithelial lineage differentiation.

Gastric gland is divided into four domains; pit, isthmus, neck, and base domains (from upper to bottom of gland). There are three principal lineages (pit, parietal, and zymogenic) in the glandular epithelium. All three lineages originate from a single multipotent stem cell located in the isthmus region. The pit cell lineage differentiates during an upward migration whereas the zymogenic cell lineage differentiates to neck and chief cells during a downward migration. The parietal cell lineage differentiates within the isthmus, and migrates up to the pit or down to the base.

膜表層細胞の過形成が見られる31).

このようにアクチン結合タンパク質である Hip 1r, エズリンは胃酸分泌プロトンポンプに対しては直接 に作用することなく, 細管小胞と管腔側膜との膜融 合やエンドサイトーシスに関わることによってプロ トンポンプのトラッフィキングや機能制御に関与す る. Hip1r, エズリンを欠損させたマウスの胃酸分泌 におけるフェノタイプでは丁度反対の性質を示すこ とも興味深い.

\section{5. 胃粘膜構築における胃壁細胞の働き}

胃壁細胞は胃酸の分泌を行うほか, 胃粘膜細胞が 正常に分化して組織を構築する上でも重要な役割を 果たす．胃粘膜を構成する細胞は，胃腺の isthmus 部 分に存在する幹細胞から分化する (Fig. 4). 幹細胞 が isthmus部分から表層に向けて移動すると pre-pit cells, 粘液分泌を行う pit cellsへと分化する. 他方, 幹細胞が isthmus 部分から胃腺底部に向けて移動する と pre-neck cells, 粘液分泌を行う neck cells（副細胞） へと分化する. neck cellsはさらにペプシノゲン分泌 を行う chief cells (主細胞) に分化する. また, 幹細 胞は isthmus部分で pre-parietal cells, parietal cells 
（胃壁細胞）に分化し，胃腺の表層，底部の両方向に 移動する ${ }^{32)}$. 副細胞から主細胞への分化過程で壁細 胞の存在が重要となる．実際に胃壁細胞が減少する と, それに対応して主細胞数が減少し, 多数の副細 胞が増殖する例が認められる ${ }^{33)}$ ．おそらくは胃壁細 胞が傍細胞的に分泌する栄養因子が副細胞から主細 胞への分化を促すものと思われる. 胃壁細胞からは TGF- $\alpha$ のほか, EGFリガンドである Amphiregulin (AR)やヘパリン結合性 EGF-like growth factor (HBEGF)が分泌される. ARやHB-EGFの発現はガスト リンによって活性化を受ける ${ }^{34)}$ 。このうち，ARをノ ックアウトすると, 胃腺の萎縮や胃壁細胞数の著し い減少が見られ, 粘液中への spasmolytic polypeptide の発現を特徵とする化生（SPEM）や腸上皮化生 （IM）が起こる ${ }^{35)}$. 特にIMはヒトにおいて前がん状 態として位置づけられている，このように，胃壁細 胞は胃酸分泌のみならず，胃粘膜上皮細胞の分化や 組織構築のキープレーヤーとして機能する.

\section{謝 辞}

本総説執筆の機会を与えてくださいました京都府 立医科大学・丸中良典教授に心より感謝申し上げ ます。

\section{文献}

1) Asano S, Morii M, T akeguchi N : Biol. Pharm. Bull., 27, 1-12 (2004)

2) 浅野真司, 森井孫俊 : Membrane, 31, 127-134 (2006)

3) Toyoshima C, Nakasato M, Nomura H, Ogawa H : Nature, 405, 647-655 (2000)

4) Toyoshima $\mathrm{C}$, Nomura $\mathrm{H}$ : Nature, 418, 605-611 (2002)

5) Toyoshima C, Mizutani T: Nature, 430, 529-535 (2004)

6) Toyoshima $\mathrm{C}$, Nomura $\mathrm{H}$, Tsuda $\mathrm{T}$ : Nature, 432, 361-368 (2004)

7) Sørensen TL, Moller JV, Nissen P : Science, 304, 16721675 (2004)

8) Morth JP, Pedersen BP, Toustrup-Jensen MS, Sørensen TL, Petersen J, Andersen JP, Vilsen B, Nissen P : Nature, 450, 1043-1049 (2007)

9) Shinoda T, Ogawa H, Cornelius F, Toyoshima C : Nature, 459, 446-450 (2009)

10) Asano S, Yoshida A, Yashiro H, Kobayashi Y, Morisato A, Ogawa H, Takeguchi N, Morii M : J. Biol. Chem., 279, 13968-13975 (2004)

11) Munson K, Garcia R, Sachs G : Biochemistry, 44, 52675284 (2005)

12) Abe K, Tani K, Nishizawa T, Fijiyoshi $Y$ : EMBO J., 28 1637-1643 (2009)

13) Abe K, Tani K, Fujiyoshi Y : Nat. Commun. Doi : 10.1038/ncomms1154 (2011)
14) Morii $M$, Yamauchi $M$, Ichikawa $T$, Fujii $T$, Takahashi $Y$, Asano S, Takeguchi N, Sakai H : Involvement of the $\mathrm{H}_{3} \mathrm{O}^{+}$-Lys-164-Gln-161-Glu-345 charge transfer pathway in proton transport of gastric $\mathrm{H}^{+}, \mathrm{K}^{+}-$ATPase., J. Biol. Chem., 283, 16876-16884 (2008)

15) Song P, Groos S, Riederer B, Feng $Z$, Krabbenhöft A, Smolka A, Seidler U : J. Physiol., 587, 3955-3965 (2009)

16) Song P, Groos S, Riederer B, Feng Z, Krabbenhöft A, Manns MP, Smolka A, Hagen SJ, Neusch C, Seidler U : J. Biol. Chem., 286, 14120-14128 (2011)

17) Heitzmann D, Grahammer F, von Hahn T, Scmitt-Gräff A, Romeo E, Nitschke R, Gerlach U, Lang HJ, Verrey F, Barhanin J, Warth R: J. Physiol., 561, 547-557 (2004)

18) Roepke TK, Anantharam A, Kirchhoff P, Busque SM, Young JB, Geibel JP, Lerner DJ, Abbott GW : J. Biol. Chem., 281, 23740-23747 (2006)

19) Fujita $A$, Horio $Y$, Higashi $K$, Mouri $T$, Hata $F$, Takeguchi N, Kurachi Y : J. Physiol., 540, 85-92 (2002)

20) Fujii T, Takahashi $Y$, Ikari A, Morii M, Tabuchi $Y$, Tsukada K, Takeguchi N, Sakai H : J. Biol. Chem., 284, 619-629 (2009)

21) Boettger T, Hübner CA, Maler H, Rust MB, Beck FX, Jentsch TJ : Nature, 416, 874-878 (2002)

22) Xu J, Song P, Miler ML, Borgese F, Barone S, Riederer B, Wang Z, Alper SL, Forte JG, Shull GE, Ehrenfeld J, Seidler U, Soleimani M : Proc. Natl. Acad. Sci. USA, 105, 17955-17960 (2008)

23) Urushidani T, Chow D, Forte JG : J. Membr. Biol., 168, 209-220 (1999)

24) Mizukawa $Y$, Nishizawa T, Nagao T, Kitamura K, Urushidani T: Am. J. Physiol., 282, C786-C795 (2002)

25) Sachs G, Shin JM, Vagin O, Lambrecht N, Yakubov L, Munson K : Clin. Gastroenterol., 41, S226-S242 (2007)

26) Forte JG, Black JA, Forte TM, Machen TE, Wolosin JM : Am. J. Physiol., 242, G349-G358 (1981)

27) Wolosin JM, Forte JG : J. Biol. Chem., 256, 3149-3152 (1981)

28) Jain RN, Al-Menhali AA, Keeley TM, Ren J, El-Zaatari M, Chen X, Merchant JL, Ross TS, Chew CS, Samuelson LC : J. Clin. Invest., 1 18, 2459-2470 (2008)

29) Hanzel DK, Urushidani T, Usinger WR, Smolka A, Forte JG : Am. J. Physiol., 256, G1082-G1089 (1989)

30) Tamura A, Kikuchi S, Hata M, Katsuno T, Matsui T, Hayashi H, Suzuki Y, Noda T, Tsukita S, Tsukita S : J. Cell Biol., 169, 21-28 (2005)

31) 浅野真司: Membrane, 35, 278-284 (2010)

32) Mills JC, Andersson N, Stappenbeck TS, Chen CCM, Gordon JI :J. Biol. Chem., 278, 46138-46146 (2003)

33) Goldenring JR, Nomura S : Am. J. Physiol., 291, G999G1004 (2006)

34) Tsutsui S, Shinomura Y, Higashiyama S, Higashimoto Y, Miyazaki Y, Kanayama S, Hiraoka S, Minami T, Kitamura S, Murayama Y, Miyagawa J, Taniguchi N, Matsuzawa Y : 
Biochem. Biophys. Res. Commun., 235, 520-523 (1997)

35) Nam KT, Lee H-J, Mok H, Romero-Gallo J, Crowe Jr JE, Peek RM, Goldenring JR : Gastroenterology, 136, 12881296 (2009)

(Received 19 August 2011;

Accepted 14 September 2011)

著者略歴

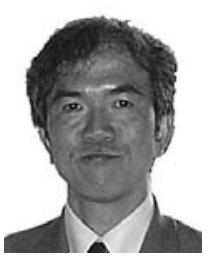

2008 年 4 月 立命館大学薬学部 教授

現在に至る 